\title{
Proximate Composition and Mineral Content of Traditionally Dried Fish Products from Selected Parts of Ethiopia
}

\author{
Bezuayehu Gutema*, Fikadu Hailemichael \\ Food Science and Nutrition Research, National Fishery and Aquatic Life Research Center, Ethiopian Institute of Agricultural Research, \\ Sebeta, Ethiopia
}

Email address:

bezuayehug7@gmail.com (B. Gutema)

*Corresponding author

\section{To cite this article:}

Bezuayehu Gutema, Fikadu Hailemichael. Proximate Composition and Mineral Content of Traditionally Dried Fish Products from Selected Parts of Ethiopia. Advances in Applied Sciences. Vol. 6, No. 1, 2021, pp. 10-13. doi: 10.11648/j.aas.20210601.12

Received: February 12, 2021; Accepted: April 9, 2021; Published: April 23, 2021

\begin{abstract}
Drying is one of the old aged food preservation techniques that can be done efficiently in a cost-effective way. Rural fish producing areas in Ethiopia commonly use drying technique when the need for preservation is necessitated. Despite the relevance of the information, nutrient composition of dried fish products found in Ethiopia are not well recorded. This study was designed to evaluate the proximate composition and some mineral content of traditionally dried fish from sites located around the lakes of Tana, Ziway and Chamo in Ethiopia. A total of eighteen composite samples were analyzed for proximate composition and mineral content determination. The dried fish products had high crude protein $(52.21$ to 70.88$) \%$, crude fat (2.89 to 8.60)\% and minerals such as Calcium (36.44 to $9078.44 \mathrm{mg} / 100 \mathrm{~g}$ ), Potassium (636.61 to $3073 \mathrm{mg} / 100 \mathrm{~g}$ ), Phosphorous (570 to $5330 \mathrm{mg} / 100 \mathrm{~g}$ ) and Sodium (78.92 to 7433.26). Because of difference in water content of the final dried product, variations were observed on the major nutrient compositions. Dried fish products generally proved to be important source of protein, energy and minerals. Besides the composition, dried fish products can be stored for extended time, thus increase accessibility of nutritious food. However, improvement of the drying technique, including hygienic processing is necessary.
\end{abstract}

Keywords: Dried Fish, Proximate Composition, Mineral Content, Ethiopia

\section{Introduction}

Fisheries play a significant role in alleviating food and nutrition insecurity for the very poor in most developing countries. Due to its incredible nutrient composition, the contribution of fish for proper nourishment and health is a widely documented fact. Fish is rich in quality protein with high bioavailability of essential amino acids, essential fatty acids and minerals such as iron, zinc, calcium, vitamin A, and vitamin B12, which in most cases lack from staple diets in low-income countries like Ethiopia [1]. In addition to importance for proper nutrition, the role of fish consumption in promoting health has been widely declared.

Drying is one of the old aged food preservation techniques that can be done efficiently in a cost-effective way. Fish drying is a common preservation practice in remote fishing areas where there is no electricity. Rural fish producing areas in Ethiopia commonly use drying technique when the need for preservation is necessitated. According to Bezuayehu and Fikadu [2], the drying procedures used in these areas are rudimentary and improvement is suggested to obtain nutritional benefits with acceptable quality.

Dried fish is a rich source of important macro nutrients (protein and lipid) and minerals (calcium, iron and zinc) [3]. The nutrient composition of dried fish in Ethiopia are not well recorded although the knowledge on nutritional composition is important to understand the association between production, access, and nutrient intakes [4]. In addition, this information can be used in devising policy and programs.

The objective of this study was to determine and document the proximate composition and some mineral content of traditionally dried fish products from three lakes: Tana, Chamo and Abaya. 


\section{Materials and Methods}

Samples were collected from major dried fish producers located based on Lake Tana, Lake Ziway and Lake Chamo. From the Lake Tana site, samples were collected from Bahirdar, Werota and Enfranz sub-sites which are located in the south, east and northern part of Lake Tana respectively. In lake Chamo site, samples were collected from two sub-sites namely Gint and Dedo sub-sites. In lake Ziway, the majority of dried fish producers are found only on the Tulu gudo island, from which samples were collected. Description of all the samples is presented in (Table 1).

Table 1. Sample description.

\begin{tabular}{|c|c|c|c|}
\hline Location & Sub-site & Species & Sample code \\
\hline \multirow{3}{*}{ Lake Tana } & Bahirdar & L. barbus & BB \\
\hline & Werota & L. barbus & WB \\
\hline & Enfranz & C. gariepinus & EG \\
\hline \multirow{2}{*}{ Lake Chamo } & Gint & L. niloticus & GN \\
\hline & Dedo & C. gariepinus & DG \\
\hline Lake Ziway & Tulu gudo & C. carpio & $\mathrm{TC}$ \\
\hline
\end{tabular}

From each sampling sub-site (Table 1), samples were purchased from six randomly selected dried fish producers. Depending on the size of dried fish, three to six dried fish were collected for each species, and kept as one sample in a polyethylene package. Samples for proximate composition and mineral content determination were kept in an insulated icebox. All the samples were transported to the National Fishery and Aquatic Life Research Center (NFALRC) laboratory for analysis.

\subsection{Proximate Analysis}

\subsubsection{Determination of Moisture}

Moisture content was determined by the reduction in weight after the sample dried to a constant weight in an oven. About $2 \mathrm{~g}$ of grinded fish sample was weighed into a silica dish which was previously dried and weighed; the sample was then dried again in an oven at $65^{\circ} \mathrm{C}$ for $36 \mathrm{~h}$, cooled in a desiccator and weighed. The process was continued until a constant weight achieved [5].

\subsubsection{Determination of Crude Protein by Kjeldahl Method}

Samples were firstly digested with concentrated sulphuric acid in the presence of a small amount of copper sulphate, selenium and sufficient sodium or potassium sulphate with mercury $(\mathrm{Hg})$ as a metal catalyst. Under these conditions, the organic matter was oxidized and the protein nitrogen was converted to ammonium sulphate $\left(\mathrm{NH}_{4}\right)_{2} \mathrm{SO}_{4}$. The digestion was followed by the addition of a strong base $(\mathrm{NaOH})$ to liberate ammonia. The ammonia was distilled, trapped in $0.5 \%$ boric acid indicator which was then titrated with $0.01 \mathrm{M} \mathrm{HCl}$. Almost all organic forms of nitrogen were converted to ammonia by the conditions of the digestion. The result of Kjeldahl analysis is usually expressed as crude protein. And then the weight of nitrogen in a sample was converted to protein using the appropriate factor based on the percentage of nitrogen in the protein sample. To convert gram of nitrogen to gram of protein, the common factors 6.25 was used. The nitrogen value was therefore multiplied by 6.25 to get the weight of protein [1].

\subsubsection{Determination of Crude Fat}

Total lipid was extracted by diethyl ether solvent system [6]. $5 \mathrm{~g}$ of the sample was weighed and extracted into a 250 $\mathrm{ml}$ round-bottom flask with $50 \mathrm{ml}$ diethyl ether for about 4 hours at $110^{\circ} \mathrm{C}$ in the soxhlet extractor. Then after, the organic solvent was removed at $40-60^{\circ} \mathrm{C}$ under reduced pressure using a rotary evaporator. Finally, the weight of fat was calculated using to the following formulae.

$$
\begin{gathered}
\text { Weight of fat }=(\text { weight of container }+ \text { extracted } f a t)-(\text { weight of container }) \\
\text { Fat content }(\%)=\frac{(\text { Weight of } f a t ~(g))}{(\text { Weight of original sample }(g))} \times 100
\end{gathered}
$$

\subsubsection{Determination of Ash Content}

For the determination of ash content, clean crucibles were placed under a muffle furnace at $550{ }^{\circ} \mathrm{C}$ for one hour. Crucibles were moved from the furnace to desiccators and cooled to room temperature. These crucibles were weighed quickly to prevent moisture absorption. Five grams of sample was added into dried silica crucibles. Placed in a muffle furnace and the temperature were held at $550^{\circ} \mathrm{C}$ for overnight. The crucibles were taken to desiccators and cooled to room temperature. After cooling, crucibles were weighed immediately to prevent moisture absorption [7]. Finally, calculation of the ash content was performed using the following question.

$$
\text { Ash }(\%)=(\text { Weight of ash }) /(\text { Wt of sample }) \times 100
$$

\subsection{Determination of Mineral Content}

About $5 \mathrm{~g}$ of grinded sample was digested in a concentrated $\mathrm{HNO}_{3}$ and quantitatively transferred to a $50 \mathrm{ml}$ volumetric flask [8]. Then the volume adjusted using a distilled water. A blank digest was prepared in the same way. After preparation of the digest, $\mathrm{Na}, \mathrm{K}, \mathrm{Ca}$ and $\mathrm{P}$ were determined using atomic absorption spectroscopy.

\subsection{Statistical Analysis}

Data was analyzed using JMP Pro version 13 software. Mean comparisons were carried out using Analysis of 
Variance (ANOVA) and results with $p<0.05$ were considered statistically significant. Comparisons between mean values of statistically significant parameters across dried fish producers were done using Tukey`s multiple comparison test.

\section{Results and Discussion}

Proximate composition and mineral content of dried fish products from the different sampling sites are presented in (Table 2) and (Table 3) respectively. Mean \pm standard deviation of triplicated proximate determination and duplicated mineral analysis were presented in the tables.

\subsection{Proximate Composition}

The finding of this study shows all proximate parameters except the calculated carbohydrate content varied significantly $(p<0.05)$ between the different dried fish products obtained from the different sites. Moisture content of these samples ranged between 14.57 in GN to 27.44 in WB samples. The variation in moisture content could be as a result of the difference in preparation technique which mainly varies in the amount of added salt and level of sun drying. For instance, the lowest moisture content in GN samples from lake Chamo site could be due to the fact that the fish drying process in that location solely relies on sun drying of thinly stripped fillets. On the other hand, in lake Tana sites, preservation by drying mainly relies on addition of salt than the sun drying process which subsequently results high moisture dried fish product as observed in WB samples. The lowest and highest protein content was $52.21 \%$ and $70.88 \%$ in WB and GN samples respectively. The low protein content of salt-dried fish compared to other fish dried without added salt could also be explained by the fact that salting could have caused loss of some portion of soluble protein. Similar findings were reported [9, 10] indicating inverse relation of the added salt and protein content of dried fish. On the other hand, the recorded fat content ranged from $2.89 \%$ in TC to $8.60 \%$ in DG samples. The lowest ash and carbohydrate content were recorded from DG samples with average composition of $4.34 \%$ and $1.12 \%$ respectively.

Table 2. Proximate composition of Ethiopian dried fish products.

\begin{tabular}{|c|c|c|c|c|c|c|}
\hline Sample & Moisture (\%) & Crude protein (\%) & Crude fat (\%) & Ash (\%) & Carbohydrate (\%) & Energy (KJ/100g) \\
\hline WB & $27.44 \pm 2.96^{\mathrm{a}}$ & $52.21 \pm 1.88^{\mathrm{c}}$ & $6.29 \pm 0.99^{\mathrm{ab}}$ & $11.95 \pm 1.44^{b}$ & $2.11 \pm 1.05$ & $273.90 \pm 7.68^{b}$ \\
\hline EG & $23.85 \pm 1.19^{\mathrm{ab}}$ & $53.32 \pm 1.76^{\mathrm{c}}$ & $6.03 \pm 0.99^{\mathrm{ab}}$ & $15.61 \pm 2.25^{\mathrm{ab}}$ & $1.19 \pm 0.71$ & $272.31 \pm 8.22^{\mathrm{b}}$ \\
\hline $\mathrm{BB}$ & $21.83 \pm 1.06^{\mathrm{abc}}$ & $58.86 \pm 1.46^{\mathrm{bc}}$ & $4.94 \pm 1.14^{\mathrm{ab}}$ & $12.67 \pm 0.89^{\mathrm{b}}$ & $1.70 \pm 0.41$ & $286.71 \pm 11.15^{\mathrm{b}}$ \\
\hline $\mathrm{TC}$ & $17.35 \pm 1.11^{\mathrm{bc}}$ & $60.81 \pm 2.37^{b}$ & $2.89 \pm 1.22^{\mathrm{b}}$ & $17.25 \pm 1.01^{\mathrm{a}}$ & $1.70 \pm 0.27$ & $276.07 \pm 6.68^{b}$ \\
\hline DG & $15.28 \pm 3.65^{\mathrm{bc}}$ & $70.66 \pm 3.15^{\mathrm{a}}$ & $8.60 \pm 1.18^{\mathrm{a}}$ & $4.34 \pm 1.01^{\mathrm{c}}$ & $1.12 \pm 0.79$ & $364.52 \pm 6.68^{\mathrm{a}}$ \\
\hline GN & $14.57 \pm 3.69^{c}$ & $70.88 \pm 0.20^{\mathrm{a}}$ & $4.80 \pm 1.00^{\mathrm{b}}$ & $4.38 \pm 0.05^{\mathrm{c}}$ & $5.37 \pm 2.75$ & $348.21 \pm 19.53^{\mathrm{a}}$ \\
\hline
\end{tabular}

Values (Mean $\pm \mathrm{SD}$ ) with different superscripts in columns are significantly different at $\mathrm{p}<0.05$.

\subsection{Mineral Content}

Summary of the mineral composition of dried fish samples is presented in (Table 3). The highest and lowest phosphorous value were $5330 \mathrm{mg} / 100 \mathrm{~g}$ in DG and 610 $\mathrm{mg} / 100 \mathrm{~g}$ in EG samples respectively (Table 3 ). In a study by Abbey et al [11], a phosphorous content of $93.71 \mathrm{mg} / 100 \mathrm{~g}$ was reported in Brachydeuterus auritus species. Whereas Jahan et al., [12] found a phosphorous content in a range between $94 \mathrm{mg} / 100 \mathrm{~g}$ to $191 \mathrm{mg} / 100 \mathrm{~g}$ in L. rohita and $P$. sophore fish species respectively.

Calcium content was found between $36.44 \mathrm{mg} / 100 \mathrm{~g}$ in GN to $9078.44 \mathrm{mg} / 100 \mathrm{~g}$ in DG. In other studies, Calcium content ranging from $248 \mathrm{mg} / 100 \mathrm{~g}$ in L. rohita to $822 \mathrm{mg} / 100 \mathrm{~g}$ in $C$. reba were reported $[12,13]$. Significantly higher $(p<0.05)$ differences were observed in calcium content of all samples in our study while the difference in Calcium content between species were insignificant in a study by Jahan et al., [12]. This could be due to the difference in sampling portion i.e., whole part of the fish was analyzed in some species whereas, only the dried fillet part was used in other samples in order to consider the edible portion in the analysis.

It was also recorded that the sodium content varied from $78.92 \mathrm{mg} / 100 \mathrm{~g}$ in TC to $7433.26 \mathrm{mg} / 100 \mathrm{~g}$ in WB. Similarly, high potassium content was observed ranging from $886.3 \mathrm{mg} / 100 \mathrm{~g}$ in EG to $3073.37 \mathrm{mg} / 100 \mathrm{~g}$ in WB samples. It was generally noted that the mineral content of the sampled dried fish is significantly different $(p<0.05)$ between the different samples. The observed variations could be due to the concentration of elements in the local environment or the chemical form of the element [14]. Despite the variations between the samples, high level of minerals was recorded in all the dried fish samples, indicating the importance of dried fish products as a source of minerals.

Table 3. Mineral content of Ethiopian dried fish products.

\begin{tabular}{|c|c|c|c|c|}
\hline Sample & Phosphorus (mg/100g) & Calcium (mg/100g) & Sodium (mg/100g) & Potassium (mg/100g) \\
\hline $\mathrm{BB}$ & $610 \pm 0.12^{\mathrm{c}}$ & $220.06 \pm 16.3^{\mathrm{e}}$ & $5187.18 \pm 24.3^{b}$ & $636.61 \pm 4.9^{\mathrm{a}}$ \\
\hline WB & $720 \pm 0.02^{c}$ & $701.4 \pm 5.7^{\mathrm{c}}$ & $7433.26 \pm 44.9^{\mathrm{a}}$ & $3073.37 \pm 16.3^{\mathrm{a}}$ \\
\hline EG & $570 \pm 0.02^{c}$ & $271.55 \pm 11.4^{\mathrm{d}}$ & $4827.52 \pm 9.2^{\mathrm{c}}$ & $886.3 \pm 4.4^{\mathrm{a}}$ \\
\hline GN & $920 \pm 0.31^{\mathrm{c}}$ & $36.44 \pm 6.4^{\mathrm{f}}$ & $104.77 \pm 6.4^{\mathrm{e}}$ & $1708.14 \pm 11.7^{\mathrm{a}}$ \\
\hline DG & $5330 \pm 0.01^{\mathrm{a}}$ & $9078.44 \pm 62.6^{\mathrm{a}}$ & $344.02 \pm 11.2^{\mathrm{d}}$ & $938.22 \pm 9.8^{\mathrm{a}}$ \\
\hline $\mathrm{TC}$ & $2150 \pm 0.06^{\mathrm{b}}$ & $2013.33 \pm 14.7^{b}$ & $78.92 \pm 7.5^{\mathrm{f}}$ & $1534.59 \pm 12.4^{\mathrm{a}}$ \\
\hline$P$ value & $<0.0001$ & $<0.0001$ & $<0.0001$ & 0.5438 \\
\hline
\end{tabular}

Values (Mean $\pm \mathrm{SD}$ ) with different superscripts in columns are significantly different at $\mathrm{p}<0.05$. 
In general, this research found significant variations between the compositions of the different dried fish products. Similar reports have been reported from previous studies [12, $13,15]$. The observed variation in composition could be due to various factors such as species, sex, maturity state, feeding condition and seasonal variations. Besides, the technique of preparation might also have considerable effect on the composition as reflected by most of the analyzed samples. For instance, BB and WB samples showed significant variation in most of their composition analysis although both were prepared using $L$. barbus species from lake Tana.

\section{Conclusion}

Nutritional value of traditionally prepared dried fish was studied from villages located around three lakes in Ethiopia. The study observed significant variations between the dried fish sample compositions. Since samples were collected from edible parts of the dried fish, the difference in composition might be mainly due to variation in local concentration of nutrients. Proximate composition and mineral content of the tested samples demonstrated that dried fish can serve as important component in nutritious diet by contributing as a source of protein, fat and important minerals. Besides high nutrient composition, dried fish products can be stored for extended time, thus increase accessibility of nutritious food if prepared following good hygienic practices.

\section{References}

[1] Dewey, K. G., \& Brown, K. H. (2003). Update on technical issues concerning complementary feeding of young children in developing countries and implications for intervention programs. Food and nutrition bulletin, 24 (1), 5-28.

[2] Gutema, B., \& Hailemichael, F. (2021). Microbial Quality of Traditionally Dried Fish Products from Selected Parts of Ethiopia. Frontiers in Environmental Microbiology, 7 (1), 1.

[3] Basu, K. P. and Gupta, K. "Biological value of protein of some species of Bengal fish by nitrogen balance and growth methods," J. of Indian chem. soc., Calcatta, pp. 543-548, 2004.

[4] Thilsted SH, Wahab MA. Pond polyculture technologies combat micronutrient deficiencies and increase household income in Bangladesh. CGIAR Research Program on Aquatic
Agricultural Systems. Penang, Malaysia. Policy Brief. 2014; AAS-2014-09.

[5] Oladipo I. C. and Jadesimi S. O. (2013). Nutritional and microbial quality of fresh and dried Clarias gariepinus and Oreochromis niloticus

[6] Folch J., Lees M., Sloane-Stanley G. H. (1957): A simple method for the isolation and purification of total lipides from animal tissues. J. Biol. Chem. 226: 497-509.

[7] AOAC (2000). Association of Official Analytic Chemists. Official method of analysis (vol. II 17th edition) of AOAC international Washington, DC, U.S.A.

[8] Association of Official Analytical Chemists. (1995). Official methods of analysis of AOAC International.

[9] Chaijan, M. (2011). Physicochemical changes of tilapia (Oreochromis niloticus) muscle during salting. Food Chemistry, 129 (3), 1201-1210.

[10] Kasozi, N., Namulawa, V. T., Degu, G. I., Kato, C. D., \& Mukalazi, J. (2016). Bacteriological and physicochemical qualities of traditionally dry-salted Pebbly fish (Alestes baremoze) sold in different markets of West Nile Region, Uganda. African journal of microbiology research, 10, 10241030 .

[11] Abbey, L., Amengor, M. G., Atikpo, M. O., Atter, A. and Toppe, J. "Nutrient content of fish powder from low value fish and fish byproducts," Food Science and Nutrition, 5 (3): $374-$ $379,2017$.

[12] S. N. Jahan, M. A. Bayezid, B. Islam, M. A. B Siddique, P. K. Karmokar, and F. A. Flowra, "Biochemical Quality Assessment of Fish Powder." American Journal of Food and Nutrition, vol. 5, no. 3 (2017): 110-114. doi: 10.12691/ajfn-53-6.

[13] Islam, M. A., Mohsin, A. B. M., Bhuiyan, A. S. and Absar, N. "Biochemical composition and nutritional value of Cirrhina reba (Hamilton, 1822) of Bangladesh," J. bio-sci., vol. 11, pp. 127-130, 2003.

[14] Windom, H., Stein, D., Scheldon, R. and Smith, J. R. "Comparison of trace metal concentrations in metals (major, essential to non-essential) composition of the different tissue of 3 demersal fish species from Iskenderun Bay, Turkey," Food Chemistry, vol. 123, no. 2, pp. 410-415, 1987.

[15] Hei, A., \& Sarojnalini, C. (2012). Proximate composition, macro and micro mineral elements of some smoke-dried hill stream fishes from Manipur, India. Nature and Science, 10 (1), 59-65. 